\title{
早池峯神社社殿と篦峯寺坊舎
}

(神仏混淆建築の研究)

$$
\text { 正会員横山秀哉* }
$$

\section{前 がき}

明治政府が樹立されると、明治元年神仏分離を定め、 同 5 年には修験道の廃止を命じ、その方もむく処は排仏 毀僠の行動と化し、特に神社において甚だしく、社寺の 建築にも影響する処大なるものがあつた。

かえりみると第 6 世紀の中頃仏教が日本へ伝えられた 当初は我国固有の神祗思想と衝突する処があつたが、特 間と共に漸くその調和がなり、先に伝えられた儒教とも 融合して、奈良朝には 3 教々全く相混合して国内宗教の 統一が出来ていた。明かに始めは神明が仏教を攡護する と考える思想であつたが、次第に神が仏力の加謢を仰ぎ 読経造仏や伽笽建立を願うと云う様な思想に軽し、平安 中期頃には神仏同体・本地垂跡の思想加泯衆一般にも広 く行われるに至り建築上にもその影響力現われてきたの も当然である。かくて中世には仏教が日本宗教の中核ど なり、社僧の進出など神儒を監理するが如き立場ともな り、漸く此の3 教一致も破絽を生ずるに至る。

即ち江戸時代の初め儒者によりまず仏教を異端邪説と する攻撃が始まり、次いで国学の與隆にともない唯一神 道論に立脚する排仏毁粎の運動に展開していつた。然し 江戸幕府は宗教政策上統一の形を堅持して、寺請制によ り伀教をして神儒 2 道を統合させていたが、こてに明治 の神仏分離を契機として神秪官の排仏主義が地方に大い に反響を与えるに至つた。かくて地方官や神官がとつた 排仏毁秎の暴挙は、たとえ神仏混淆が日本宗教界を混迷 にしていたとは云え、それらが可なりよく調和されて 1 千年の永きに互り我国思想界の支柱となつていた事実ま で抹殺せんとしたもので、これを社寺建築の上から見て も過去の歴史を不分明にした点が多く、或は故意にゆが められた点も無をにしもあらずである。然るにこれらの 点については建築史学上従来殆んど無関心の感がある が、当然検討が加えられる必要加あると考えられる。

しかも神仏分離以後における排仏毁粎は国家神道を背 景として可なり徹底したものであつたから、分離上前の 混淆の様相を知ることさえ現在では資料に乏しく、更に 中世以前にまで溯つて神仏習合の実態を把握するととは 容易ではない。

然し民族の宗教的伝承と云うものは根強いものがあ る。たとえ神仏汃分離され一応混淆の行事や生活が改変 された筈の今日でも尚その遺風か残存する社寺が稀には

*東北大助教授，工博
あり、維持監理などの都合上建築的には案外分離以前の 旧態のまま継承されている遺構もあり得ると思われるか ら、広くそれらの資料を蒐集検討されるととが望まれ る。ともかく今日の段階では調查の主なる対象として、 わつて神仏混淆的な行事の顕著であつた仏堂社殿行場の 類と、それらに関与した人々の生活した院坊居宅等があ ると考えられる。然しそれらの資料当江问時代の宗教政 策の枠に一応統制された姿以上には求め難いであらうか ら、さらに湖つて究明するためには関係史料の探求と、 宗教学或は民俗学的な方面などからも神仏習合の思想、 行事作法の実態、生活の在り方等が考察検討されねばな らぬであろう。

装池篷神社は岩手県遠野市の北方へ約 $23 \mathrm{~km}$ 猿石川 に沿つて湖つた附馬年村字大出 (現在は遠野市入編入) そある。霊山早池峯の遠野口拝登路の本社で(注 1)、社前 より登山路は薬師岳を越え、河原坊から七里の河原を経 て早池峯の御門口に達し、それより急坂を山頂まで登る と奥宮力鎮座する。

早池峯は東に安倍山、西に䌖頭山、南に薬師岳（医王 山) 北々中岳を徒え北上連峯の主峯で海拔 $1913 \mathrm{~m}$ 、古 くから民間信仰の霊地で修験国峯の一に数えられた。

大出の佐々木重太氏所蔵の早池莑山縁起 (元禄11年、 当時の別当妙泉寺 52 世宥盛手記）によると、大同年中 来内村の猟師藤蔵が早池峯山頂において神霊を感得し、 発心して参道を開き山頂に 1 宇を建立しててれを祀るに 始まる。のち藤蔵は長子兵庫と共に山麓大出村に移り、 薙髸して普賢坊と称し、兵庫も亦長円坊と号してその跡 をうけて権現に奉仕し、承和 14 年には山頂の1宮を改 わて若宮 (又は大宮) と本宮の 2 社とした。

然して斉衡年中（一説に嘉祥年間）慈覚大師円仁が巡 錫して霊峯の来由を聞き、大出村に 1 寺を建立して早池 峯山持福院妙家寺と号し、権現の本地十一面観音を祀 り、薬師虚空蔵両苔薩を以つて脇士となしてれを新山宮 と称した。或は仁王像を嚸んで山門に安置し、又坊舎に 不動明王及び大黒天を彫んで大黒坊とも号した。高弟 1 人をとどめて別当となし、長円坊の子孫をしては永く爾 宜として神事を司らせたと云う(注2)。

勿論これら草創の縁起の信疑は証し難いが、文治 5 年 (1189) 及び宝治元年 (1247) の火災が伝えられている。 宝治 2 年遠野の住紺野新左衛門尉が再興し、又文安年中 
に至つて遠野城主阿曾沼参河守禅頭も供料若干を寄せて 保護した。寛永 4 年 (1627) 南部弥六郎直栄が八戸より 遠野（横田城）に移ると寺社領 135 石を安堵し、その後 加増して 200 石が給せられていた。

別当妙泉寺は寛治年中 16 世修徳の代に天台より真言 に改宗されたと伝えられ、姃宝 5 年幕府より本末を質さ れた時大和の豊山長谷寺を本寺とした。然し早池峯は古 来国萃として信仰を集內、新山宮が神仏混淆の修験道的 行法によつて奉仕されていたものと考えられる。例えば 前記縁起に載せる新山宮の正月七日堂の祭祀では、

年々自臘月晦日、以至干朋年正月七日、首尾七穄日之 項、参籠宮中。而有行法及読経、三時之勤行也。既至 干六日之朝、勤修正供及護摩供。

干時守札牛王大黒御影駒形等、皆加持而一歳之際朋 ¿o

とするが、毎歳 6 月 18 日の新山宮大祭では、

干時神興行幸襍川。爾宜捧憋帛。囲列神興之左右、職 正之神楽男合調拍子除御前。民子之児童擎榊葉陣御 後。還幸亦復如是。然而奉遷神体於内陠、供法味修咒 経。爾宜办勤祝詞及祈湯託宣等之事。

と見られるが如きである。然し別当妙泉寺は明治初年の 神仏分離によつて廃せられ(注 3 )、以後そのまま早池峯神 社と改称されたが、古老は今も尚「おシンザン」と呼ん でいる。

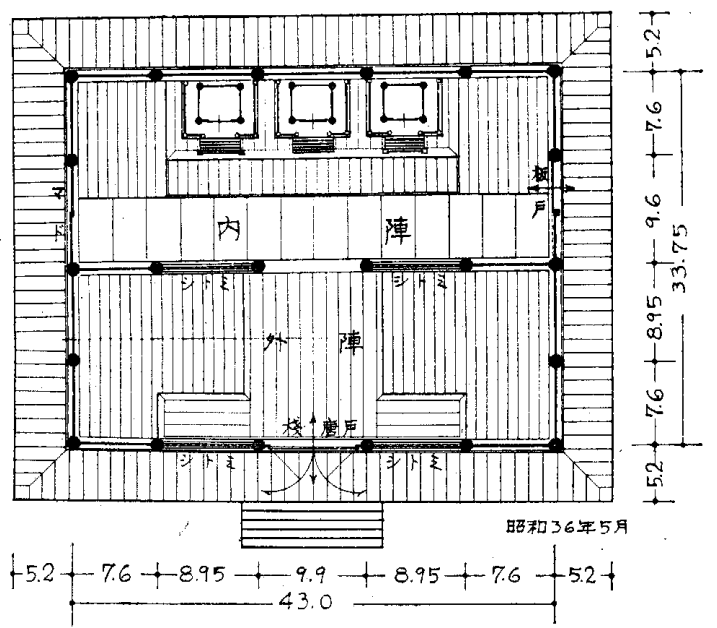

第 1 図 岩手県遠野市附馬牛町大出早池崒神社

現在の早池蜜神社は本殿・拝殿・神門及び社務所・黑 門から成るが、それら法泹妙泉寺の本堂（新山宮）・择 砒 (長床) ・山門（仁王門)(注4) 及び庫裡・御成門に当 るわけで、排伀毁釈の洗礼を受けたにもかかわらず建物 は幸い旧状を伝えている。現本殿について前記縁起に、

自宝治二年以来経星霜四百三十有余年、故新山之宮社 逮大破。是以予告于遠野領主源義論檀君。因扶助工料 夫貨材用並牛馬等之雑費。故予元禄四年辛未春企造 立、同六月終功。而同月廿八日覆宮慶賛焉。

と記し、又現存棟札に「干時元禄四辛未歳林鐘吉曜、早 池举山別当妙泉寺莸忽法印有盛九拝謹書之」とも見光、
大工棟梁は遠野住平野荘右衛門勝吉、同長男荘吉勝貞と 知られる。その規模は正面 5 間 43 尺、側面 4 間 33.75 尺、屋根は入母屋造周囲に廻縁を設けるが勾欄は無い。 主要材にナラを用い、側柱は八角で大斗舟肘木、地覆・ 内法長押のみで腰長押を用いず、正面中央は両開き棧唐 戸、その左右の間は恐で部戸をつる。軒は二軒、半繁棰 割。内部は中央で前後に仕切つて内外陆に分け、中央 1 間を開放してその左右の間は部戸となる。天井は内外陣 を通して周团の1間通りは化粧屋稂竬とし、中央部は等 縁天井となる。間仕切柱のみ円柱とし唐様の三斗組とす るが、柱閻中備えには签束置く。又外陣に架けた虹梁 上には太瓶束を置き、乙れらの科栱束等に彩色を加え る。内陣の奥には高さ 3 尺程の壇を設けて 3 棟の干鳥破 風妻人の宮殿型の厨子を置き、左右の 2 棟には特に軒唐 破風の向洋がつられており、何れも絵様彫刻彩色を施 し、飾金具が用いられ、紋様には運華文・唐草・ボタン 等仏教色が濃厚である。

今は祭神を瀬織津姫命とし、郷土に残る神通稳の神話に 従つて中央に早池客、左右に六角牛・石上の三山の女神 が祭られているが、前記の的子並びにその祭祀の状況は 神仏分離以前と変らないと云われるし、又建物内外の規 模も殆んど改変されていない（昨年に惪賞屋根を亜鉛鍍 鉄板に改め、正面中央に 1 間の向拝を增補したが明かに 区分出来る）から神仏混淆時代の建築規模を見ることの 出来る 1 遺構である。

この早池莑神社本殿と全く規を一にする遺構に福島県 田村郡船引町大字門沢字堂山の王子神社々殿がある。此 の建築も中世に田村 66 郷のうち東 33 郷を支配下に㧈 き、古くは13.坊を数えたと云われる竜頭山堂山寺の本 堂（観音堂）が明治初年の神仏分離の際神社に改められ たもので(注5)、現社殿は少くとも江石初期の建築と見ら れ重要文化財に指定されている。尚此の神社でも現在社 前に仁王門が存置されている点など早池峯神社同様であ る。

神仏混洧時代にはこれら仏堂形式の殿堂と共に、例え ば羽黒山上の出羽神社本殿（三山合祭殿）の向つて左に 建つ䈗島神社（もと弁財天堂）の如く外部意匠にも神仏

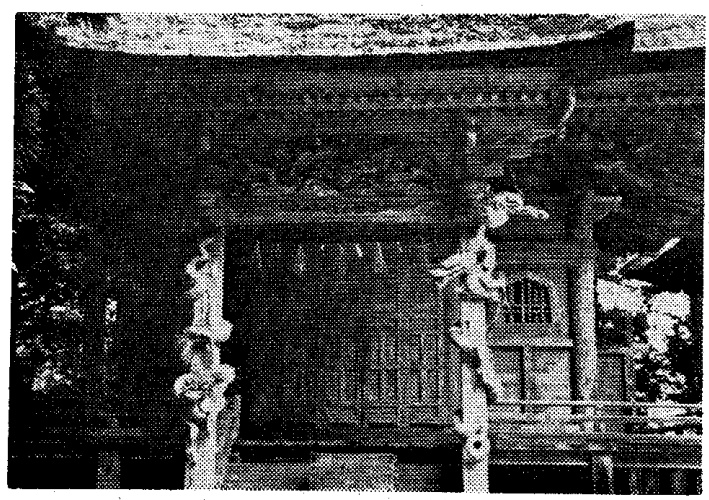

第 2 図 羽黑山上綮島神社↔殿 
混淆色が表現されていた社殿も存在した箱である。

(2)

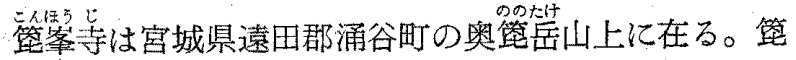
峯寺一山記録の縁起畫（宝暦 3 年文書）によると光仁天

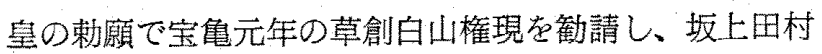
麿が東夷討伐の後山頂に十一面観音堂を建立して霧岳山 正福寺と号したが、嘉祥年中慈覚大師円仁が中興して無 夷山篦峯寺と改め、弟子尊常をして住院せしめたと市 る。或は平安初期に清水寺の延鎮の開基とも伝えられる 办、とるか人篦峯寺における正月元旦から25日に亘る 修正会並びに仁王会（今では大福田会と呼ふ）の大神事 は古式を伝㫕ているものとして有名である。即ち篦萃寺 は 20 余の院坊から成る一山の総称で、それら院坊の住 職は輪番 1 年交替に「荺前」と呼ばれて観音堂白山社を 中心に一山の行事を司り、所謂「宮座」の形式が今日ま でよく伝承され、神伀習会的な行事の形態がよく残され ている。

応永 28 年 (1421) の古鐘銘に法南谷別当子北谷別当 の名が見られるが、両別当は天正年中廃退したと伝えら れ、元亀 2 年 (1571) の「奉彩色不動毘沙門」の札銘に

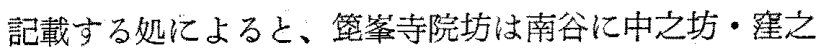
坊・林崎坊 - 仁王堂・東之坊・井上坊・熊野堂・吉祥坊 - 藤本坊・山本坊・薬師堂の11坊。北谷には大閒坊・杉 本坊・西之坊・坂本坊・桜本坊・松本坊・実相访・梅本 坊・相泉坊・林泉坊・山崎坊・荁之坊の 12 坊の名連 ら㱛ている。然していっ頃屾山本山崎の 2 坊を失い、少 くとも江戸初期加ら現在まで 21 坊か存在する。それら の院坊は幕府の宗教統制により山内に監守 1 坊を置き、

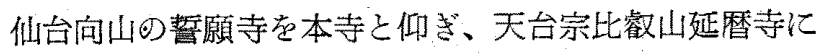
属し、伝法出世の僧寺の形態がとられるに至つた。尚と

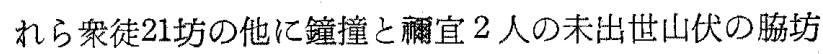
が在つて、加光て 24 坊とも称し、正保年中以来明治維 新までは合せて 12 貫 255 文の知行高を保有していた。

ここに脇坊 3 人のみが山伏の身分であつた経緯に関し 宝曆 3 年 (1753) 5 月本寺誓願寺より藩へ提出した文書 に「筑岳八往古天台宗修験兼帯之山二テ入峯修行仕』衆 徒之坊八古来山伏二而霜宜役鐘撞役相勤来候」とし、然 るに右入峯中絶以来古風山伏三人相残右爾宜役鐘撞役 相勤来候」と、臬徒 21 坊も古くは修験山伏であつたと とを明分化する。多分雨別当が廃退し近世になつてから だろうが 21 坊は山伏階級汃ら所謂出世して、後は脇坊 3 人のみが山伏のまま残つたとするのである。ここに21 坊に娄修験的性格が伝光られている理由があり、次の宽 永 19 年 (1642) の文書化よつてき全坊が清僧では無く 妻带の生活で、一代一度跻山に登つて権大僧都に補任は されていたが事実各坊とも父子相承の家柄であつた事が わかる。

$$
\text { 一、井上坊 人数拾六人 六㚻拾壳人 其身共二 }
$$

$$
\begin{aligned}
& \text { 一、窪之坊 人数四人内勇武人其身共二 } \\
& \text { 一、圾本坊 人数 四人内男武人其身共二 } \\
& \text { 一, 実相烓 人数 五人内男武人其身共二 } \\
& \text { 一、梅本坊 人数 六人内男琶人其身共二 } \\
& \text { 一, 西之坊 人数 六人内男要众其島共二 }
\end{aligned}
$$

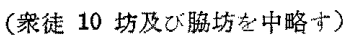

$$
\begin{aligned}
& \text { 一、薬師堂 人数 五人内男 三人其身共二 } \\
& \text { 一、化堂 人数 六人内男 致其身共二 } \\
& \text { 六人之内下人t汁 }
\end{aligned}
$$

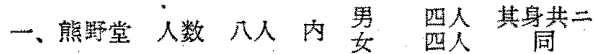

$$
\begin{aligned}
& \text { 内下如唪き } \\
& \text { 一、中之坊 人数拾五人 内 女男五人 其身共二 } \\
& \text { 一、東之坊 人数 拾人内男突人 其身共二 } \\
& \text { 右涊人数 合百武拾式人 内男 六拾四人 }
\end{aligned}
$$

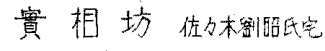

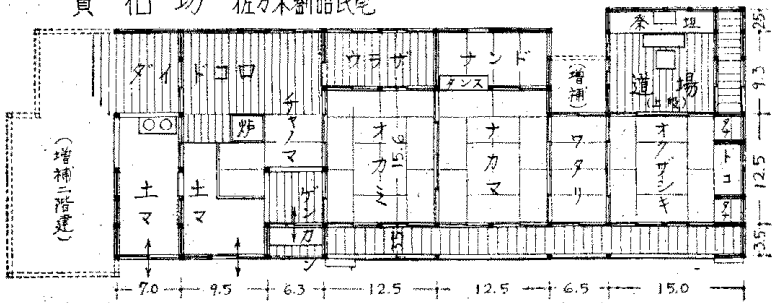

仁王堂士放室氏宅

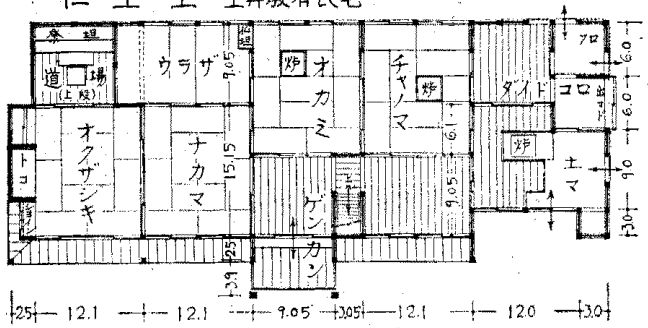

熊 野 堂 木村看海註宅

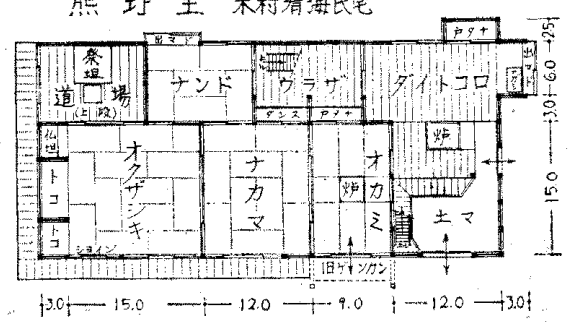

第 3 图 宫城県遠田郡涌谷町籃岳 管峯寺院坊建築 (昭和 36 年 5 月)

てれら篦箨寺院坊の建築については天保13年 (1842) 11 月 19 日の朝五ツ時に篦岳花立からの野火がもとで、 先ず梅本坊泟延焼し、強風が災して大火となり、観音堂 白山社その他諸堂宇と共に山内 11 坊まで焼失した(注 6 )。 従つて現在の院坊の大半岷大火後の再建で、罹災をま奴 がれた院坊もこの後の改築等で遺構として特に古いと諗 められるるのは無い。その中で熊野堂（木村宥海氏宅） は屋根裏部屋の天井に現机る隅梁鼻に「か永六丑二月 日、法眼志んけいサク」と彫込まれているので建築年代 の明かな例である。

筑举寺院坊の構光は寺院と云うよりは半農半僧の生活 の住居で、新裤の道場を設け玄関を構光、あるものは屋 
根を破風造にするが、その他の点は附近の一般農家と大 差はなく、その様相には羽黒山修験宿坊の建築に通ずる 処るある(注7)。即ち入口土間・オカ之・ナカマ・オクザ シキと台所・ウラザ・ナンド等から構成され、道場の設 计方に実相坊や林泉坊の如く住居棟之は别棟に道場を設 けて渡りで連続するものもあるが、多くは熊野堂や王 堂の如くオクザシキの裏側の一室に道場をとり、且つ锶

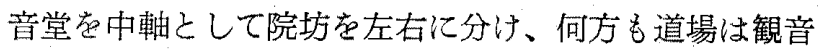
堂に近い側に設けるのを制としている。道場法 4 坪内外 の広さで板張上段にしつらえ、奥に祭壇を設计不動像等 が祀られる。大福田会の時は道場の前の座敷を結界して 正面に白山権現の軸をかけ一山衆徒が集つて神事を行う ので可なり広くとられ、ナカマを経てオクザシキ道場へ 通ずる玄関が設けられる。簡単なものは式台のみである が、王堂では軒唐破風の車寄がうけられている。調查 の結果台所趈りは各坊共改造のあとが多いが、古式に則

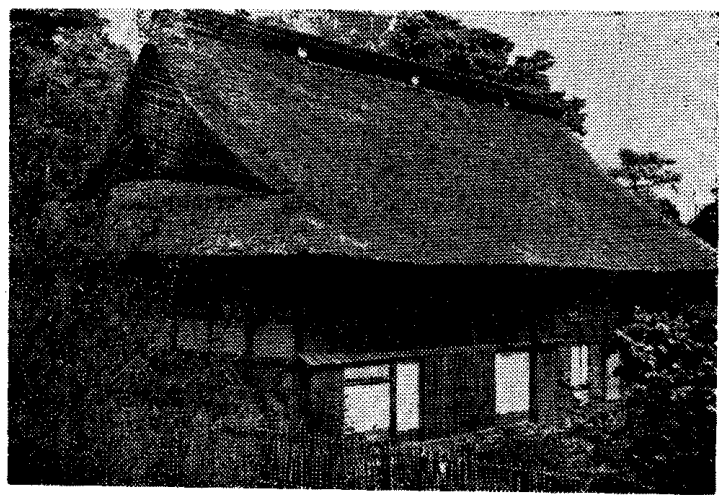

第 4 図 管峯寺山内熊野堂

る行事を守るために何れも玄関から道場敒る部分は全

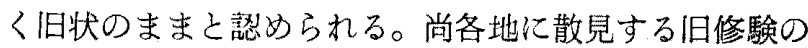
院坊住宅とその間取規模に共通点の多い事が注目され る。

福島県田村郡三春町字斎藤の伊藤急寿氏本宅はもと三 渡明神（今の見渡神社）の別当妙見山天正院の遺構であ る。天正院は旧藩時代は田村郡修験年行事の次位の席に あつたと云われ、系図書によると当主は第36代に当り、 その祖先の第 3 代敏保が厸仁年中勧学院で神仏耐道を学 び法印となり、その子第 4 代広光は聖護院㲹属して大峯 に入り修験として修行をし、その後代々法印或は神主々 して修験道の家柄である。第 29 代真山住灯阿闇梨権 大僧都法印として天明年中三春の秋田氏の為め三渡明神 々前に月々三度の祈㳯執し、以後連綿之明治維新ま で三渡明神別当職として継承され、第 34 代頼貞の時明 治 2 年神仏分離に際し名を斎子と改好鎮守見渡神社の神 官となり現在に及ぶ。

本遗構は約 130 年前旧状に従つて再築されたと伝えら
れ神前（もと道場）など莧だしく荒廃しているが、それ だけよく旧状を残すと見ることが出来る。即ち入口正面 はアヅマ中二階の此の地方一般に見られる農家之同様 (ニワに接して後補になるウマヤがあつたが近年取払わ れた）で、修験院坊としての特徽と兒られる部分はトコ ・ショインを有するオクザシキを有し、しれとならんで 上段の神前と呼ばれる1室が設けられる。今祭壇には神 鏡・御幣などが飾られるが尚ゴマダンなどの名称も残つ ている。要するに地方山間の修験は半農半僧の生活で、 本遺構は亦神仏混淆時代の修験の住様式の代表的なもの と考朰れる。

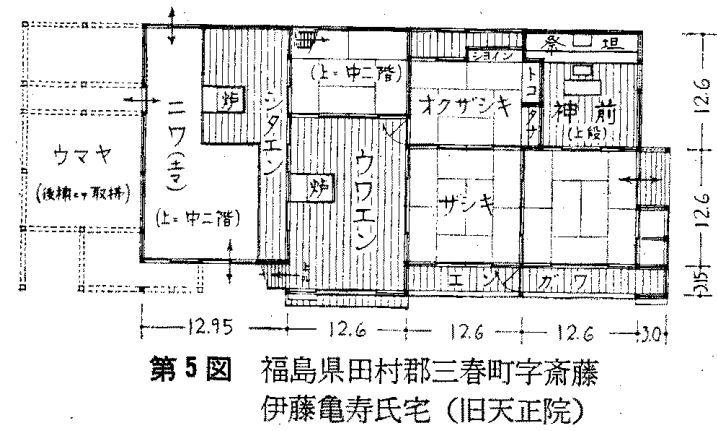

[铨]

1）早池峯择登路には南の遠野口の他に東に小国口、西に大 迫口、北汇門馬口の 3 口がある。花巻方面からの大迫口(稗 貫郡大迫町内川目）にも中世に遠野口同棣妙泉寺新山宮が 造建世られ、南部氏の藩政時代には蜜ら殷盛をきたしたが、 これも神仏分離に早池峯神社と改称されて現在に改ぶ。

2）長円㘦の後裔は始閣氏老名乗り上䌮宜（始閣実家）と下

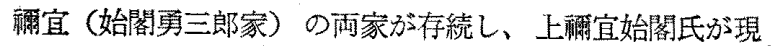
在早池峯神社の社司である。

3）妙泉寺最後の住職 60 代有応は還俗して宮本律人と名乗り 早池峯神社初代社司となるも幾ばくもなく遠野一去る。宫 本家系図書によると代々新山宮別当であり、妻帯相続の家 柄であつた。

4）拝殿は棟札に「毫保十九甲寅天初冬吉祥曜、大工白金市 兵衛凹喜」とあり、野沢武右工門（天保一文久）の著御山先 立往来に「御門注谷仙より番匠管引越、文化年中の造立也」

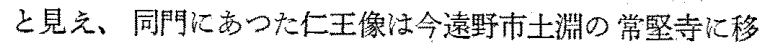
されて残る。

5)田村地方でも平田学派の急進的な徒党が仏堂破壤の挙に 出たので、堂山寺の古建築を守るために明治 3 年同村宫， 下にあつた王子権現を入れて鎮守とす。

6) 此の大火に当り藻師堂義啓が決死火中より管峯寺本尊(文 和の胎内経沉より知られる）を救出した。東大門附近にあ る碑銘に「釈義啓字素順、父者日野氏薬師堂啓宦、母者末 永氏女也。自幼䪵悟秀徹而仏等東台、往日天保王寅十一月

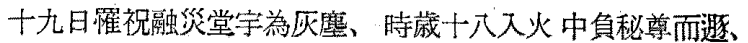
故尊客於今得全」

7）拙著「羽黑修験手向宿坊の建築」（学会研究報告第30号所 載) 参照。 